\title{
Use of monoclonal antihapten antibodies for immunolocalisation of tissue antigens
}

\author{
B JASANI, D WYNFORD THOMAS, ED WILLIAMS \\ From the Department of Pathology, Welsh National School of Medicine, Heath Park, Cardiff
}

SUMMARY The applicability of a hapten-antihapten sandwich technique incorporating a monoclonal antihapten bridge antibody to localisation of tissue antigen is described. The results show that the method is both versatile and selective and has the potential of being even more sensitive than currently used immunoperoxidase methods.

Of the various immunohistochemical techniques currently in use the peroxidase-antiperoxidase method of Sternberger has proved to be by far the most sensitive. ${ }^{1}$ The full potential of this sandwich staining procedure is however limited by two major drawbacks.

Firstly, because the overall specificity of staining is determined solely by the selectivity of the initial tissue binding of antigen-specific antiserum (primary antiserum) and since this antiserum always contains a whole host of natural immunoglobulins capable of attaching to a variety of unwanted tissue sites there is an inevitable interference from background staining to a greater or lesser degree. Secondly, the localisation of each type of bound primary antibody requires a unique set of species-specific reagents, namely antiimmunoglobulin bridge antibody and peroxidaseantiperoxidase enzyme marker. Relatively high costs and the restricted availability of such reagents limit wider applicability of this method.

In order to overcome these limitations we have recently ${ }^{2}$ proposed the use of a hapten-antihapten sandwich procedure similar to that described by Cammisuli and Wofsy ${ }^{3}$ but incorporating a monoclonal antihapten antibody as the bridge reagent between hapten-labelled primary antibody and a peroxidase enzyme marker. The present study demonstrates the practical feasibility of this approach and outlines its future potential in routine immunohistochemistry.

\section{Material and methods}

\section{REAGENTS}

Hapten-labelled primary antisera

Guinea-pig antibovine insulin and guinea-pig anti-

Accepted for publication 2 March 1981 bovine thyroid stimulating hormone (TSH) were generous gifts from Dr S Woodhead (Department of Biochemistry, Welsh National School of Medicine) and Dr B Rees-Smith (Department of Medicine, Welsh National School of Medicine), respectively. Whole serum $(50 \mu \mathrm{l})$ was treated with saturated solution $(450 \mu \mathrm{l})$ of dinitrophenyl aminoproprionitrile imido ester ${ }^{4}$ in triethanolamine- $\mathrm{HCl}$ buffer $(\mathrm{pH}$ $9.0,0.3 \mathrm{M}$ ) at $0^{\circ} \mathrm{C}$ for $5 \mathrm{~h}$. Unreacted dinitrophenyl (DNP) reagent was separated by column chromatography (Sephadex G-25 equilibrated with phosphate-buffered saline, $\mathrm{pH} 7 \cdot 2$ ). The dinitrophenylated antisera were stored at $-70^{\circ} \mathrm{C}$.

\section{Hapten-labelled peroxidase enzyme markers}

Rabbit antihorseradish peroxidase (Dakopatts) was dinitrophenylated as above and then treated with horseradish peroxidase (Boehringer Grade I) to obtain dinitrophenylated peroxidase-antiperoxidase complexes (DNP-PAP) which were purified according to the method of Mason and Sammons. ${ }^{5}$

\section{Antihapten monoclonal antibody}

Mouse antiDNP IgM and IgG monoclonal hybridoma antibodies were obtained as a generous gift from Dr M Kennedy, Institute of Medical Research, Mill Hill, London.

STAINING PROCEDURE

Bouin's fixed paraffin-embedded, $5 \mu \mathrm{m}$ sections of rat pituitary and pancreas were mounted on chrome gel slides. Endogenous peroxidase activity was abolished by the periodateborohydride method. ${ }^{6}$ The sections were then treated with neat nonimmune serum from the species providing the primary antiserum. This was followed by sequential addition of dinitrophenylated primary antiserum, antiDNP monoclonal antibody, and dinitropheny- 
lated PAP complex, under conditions summarised in the Table. The staining was developed by means of the diaminobenzidine method.?

\section{Staining sequence}

\begin{tabular}{lc}
\hline Reagent & $\begin{array}{l}\text { Duration } \\
(\text { min })\end{array}$ \\
\hline Non-immune serum (NIS) (neat) & 5 \\
Dinitrophenylated primary antiserum (1/200 in NIS) & 45 \\
Phosphate-buffered saline (PBS) & 10 \\
AntiDNP monoclonal antibody (1/10 in NIS) & 45 \\
PBS & 10 \\
Dinitrophenylated PAP (1/10 in PBS) & 45 \\
PBS & 10 \\
Diaminobenzidine/ $\mathrm{H}_{2} \mathrm{O}_{2}$ & 5 \\
PBS & 10 \\
\hline
\end{tabular}

\section{Results}

Figs. 1 and 2 represent photomicrographs of rat pancreas and rat pituitary showing peroxidase staining of insulin and TSH respectively, obtained with the above method. The granular character of the cytoplasmic staining together with the lack of background staining shows the high selectivity of the technique. Prior absorption of primary antisera with the appropriate purified antigen was found to abolish all staining, demonstrating the specificity of the method.

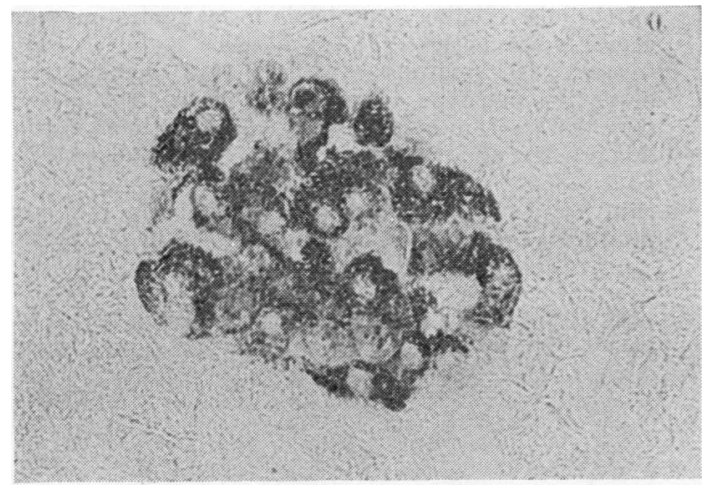

Fig. 1 Rat pancreas showing speciflc staining of islet cells by hapten-sandwich technique. $\times 480$.

\section{Discussion}

Virtually all sera contain a variety of "natural" antibodies having the capacity to bind to various tissue antigens, in particular blood group and histocompatibility antigens. ${ }^{8} 9$ The serum concentration of such antibodies is often sufficiently great to cause

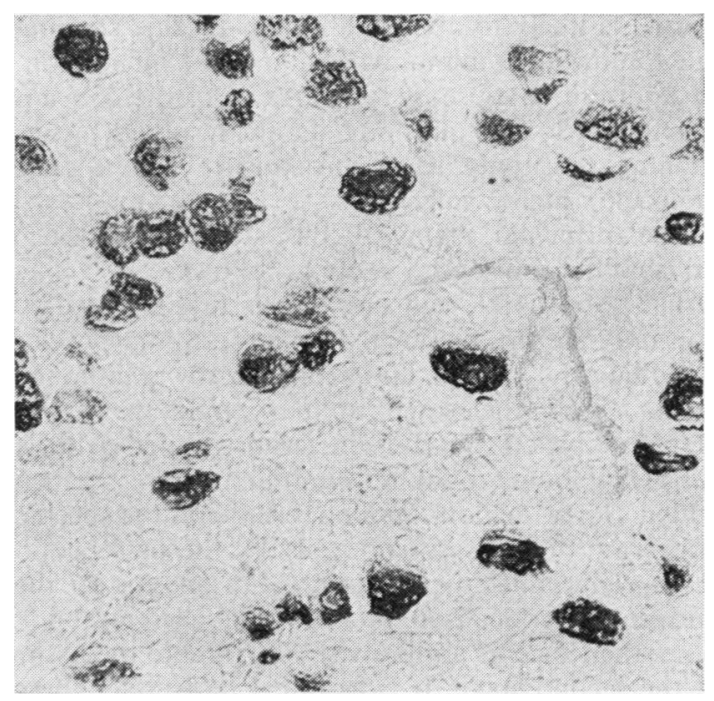

Fig. 2 Rat pituitary showing specific staining of thyrotrophs. $\times 480$.

significant background staining in immunoperoxidase procedures. ${ }^{10}$

We have found this particularly true of the immunocytochemical localisation of hormone receptors, the numbers of which in tissue for certain polypeptide hormones may be as low as one receptor per square micron. ${ }^{11}$ Complete inhibition of any background staining is clearly essential if antigens of such low concentration are to be demonstrated. It is perhaps not surprising that very few studies can be accepted as showing immunocytochemical visualisation of polypeptide hormone receptors at the light microscopic level. ${ }^{12} 13$

Antibodies heavily substituted with hapten have proved effective in localising "weak" antigens such as a variety of mouse lymphocyte surface determinants, ${ }^{3}$ the staining of which has not hitherto been possible even with Sternberger's highly sensitive PAP method.

The recent introduction of monoclonal antibodies ${ }^{14}$ is obviously of considerable importance to the improvement of the selectivity of immunohistochemical staining. Making use of these recent developments we have designed a technique which incorporates an IgM monoclonal antibody to a hapten which can be easily linked to a minute quantity of antibody contained in microlitre amounts of serum. The use of such hapten-labelled antibody allows for its localisation when the tissue has first been exposed to unlabelled serum from an unimmunised animal of the same species which should contain virtually all tissue binding antibodies except the specific one. This procedure (discussed in detail 
below) is likely to abolish any non-specific staining due to unwanted immunoglobulin-tissue interaction. In addition, the use of IgM instead of the conventional IgG bridge antibody should result in higher staining sensitivity as a consequence of the $\operatorname{IgM}$ molecule's higher valency.

The principal steps in the staining sequence utilising the above criteria are as follows:

The tissue section in question is first exposed to non-immune serum obtained from the animal species providing the specific antiserum. Ideally preimmune serum from the same animal could be used. Hapten-labelled specific antiserum diluted with a further amount of the non-immune serum, is then added. Since the non-immune serum and the specific antiserum differ essentially only by the presence in the specific antiserum of antibodies specific to the antigen being localised, no hapten-labelled antibody other than specific antibody should bind to the tissue at the second stage. It is assumed that under these conditions there is no significant specific or nonspecific exchange between unwanted labelled and unlabelled proteins. The hapten-labelled specific antibody bound to the tissue section is then localised with extremely high specificity using monoclonal, monospecific anti-hapten hybridoma antibodies directly or indirectly linked to a peroxidase enzyme marker system.

It is evident from the present study that the use of the same hapten for labelling a variety of primary antisera should result in the requirement of only one set of reagents for the 2 nd and 3rd steps of the sandwich procedure employed, thus rendering the technique potentially extremely versatile.

Since whole primary antiserum can be directly haptenated without prior fractionation no specialised biochemical facilities are required. The method is not only effective in preventing background staining but also has the potential of being highly sensitive. ${ }^{3} \mathrm{We}$ are currently examining its value in the localisation of such exacting tissue sites as hormone receptors.

\section{References}

${ }^{1}$ Sternberger LA. Immunocytochemistry. New York: Wiley, 1979.

2 Jasani B, Williams ED. DNP as a hapten in immunolocalisation studies. J Med Microbiol 1980;13:xv.

${ }^{3}$ Cammisuli S, Wofsy L. Hapten-sandwich labelling III bifunctional reagents for immunospecific labelling of cell surface antigens. J Immunol 1976;117:1695-1704.

${ }^{4}$ Schramm HJ. Use of imidoesters for the chemical modification of proteins: I. Synthesis of coloured nitrites, dinitrites and bifunctional imidoesters. Hoppe Seylers $Z$ Physiol Chem 1967;348:289-92.

- Mason DY, Sammons R. Rapid preparation of peroxidase: anti-peroxidase complexes for immunocytochemical use. J Immunol Methods 1978;20:317-24.

${ }^{6}$ Heyderman E. Immunoperoxidase technique in histopathology: applications, methods and controls. J Clin Pathol 1979;32:971-8.

${ }^{7}$ Graham RC, Kafnovsky MJ. The early stages of absorption of injected horseradish peroxidase in the proximal tissues of mouse kidney with structural cytochemistry by a new technique. $J$ Histochem Cytochem 1966;14:291302.

${ }^{8}$ Goldsmith KLG. Blood transfusion serology in: Gell PGH, Coombs RRA, Lachmann PJ, eds. Clinical aspects of immunology. 3rd ed. Oxford: Blackwell, 1975;195-214.

${ }^{9}$ Joysey VC. The HL A antigens and their significance. In : Gell PGH, Coombs RRA, Lachmann P.I, eds. Clinical aspects of immunology. 3rd ed. Oxford: Blackwell. 1975; 215-42

10 DeLellis RA, Sternberger LA, Mann RB, Banks PM, Nakane PK. Immunoperoxidase techniques in diagnostic pathology. Am J Clin Pathol 1979;71:483-8.

${ }^{11}$ Greaves MF. Cellular recognirion. London: Chapman \& Hall, 1975.

12 Witorsch RJ, Smith JP. Evidence for androgen-dependent intracellular binding of prolactin in rat ventral prostate gland. Endocrinology 1977;101:929-38.

${ }^{12}$ El Eltreby MF, Mahrons AT. Immunocytochemical technique for detection of prolactin (PRL) and growth hormone $(\mathrm{GH})$ in hyperplastic and neoplastic lesions of dog prostate and mammary gland. Histochemistry 1979; 64:279-86.

${ }^{14}$ Kohler G, Milstein C. Derivation of specific antibodyproducing tissue culture and tumour lines by cell fusion. Eur J Immunol 1976;6:511-9.

Requests for reprints to: Dr B Jasani, Department of Pathology, The Welsh National School of Medicine, Heath Park, Cardiff CF4 4XN, Wales. 